\title{
What Do Health Care Professionals Think About Covid-19 Vaccine Applications: A University Example
}

\section{Sağlık Profesyonelleri Covid-19 Aşı Uygulamaları Hakkında Ne Düşüinüyor: Bir Üniversite Örneği}

\author{
Șerif KURTULUȘ 1 (D), Remziye CAN ${ }^{2}$
}

\author{
${ }^{1}$ Harran University Faculty of Medicine, Department of Chest Diseases, Şanliurfa, Turkey \\ ${ }^{2}$ Nursing Public Health, Mustafa Kemal Atatürk Vocational and Technical Anatolian High School, Eskişehir, Turkey
}

\section{Abstract}

Background: Vaccination of Health Care Professionals (HCPs) is of great importance for communicable diseases. This study aimed to investigate the views of HCPs working in a university hospital about the coronavirus disease 2019 (Covid-19) vaccine and to evaluate the factors affecting vaccination.

Materials and Methods: This cross-sectional study was completed with 183 volunteers in a university hospital on 9-12 December 2020. A questionnaire consisting of 10 questions developed by the researchers was used in the study. The study was approved by the Harran University Ethics Committee (09.11.2020; session: 19; decision no: HRU / 20.19.24). In addition, the Republic of Turkey Ministry of Health's Covid-19 Study approval was received. Results: The rate of HCPs who were willing to get the Covid-19 vaccine was $53.6 \%$. Of the participants, $74.9 \%$ thought that the Covid-19 vaccine would have an effect on reducing the incidence of Covid-19. There was a significant difference between the decision on getting the Covid-19 vaccine and the effect of the vaccine on the incidence of Covid-19 ( $p=0.000)$. Getting the Covid-19 vaccine was found to be affected 2.721-fold by the male gender, 0.356 -fold by receiving vaccination during the pandemic period, and 19.272 -fold by the thought that the Covid-19 vaccine would reduce the incidence. Participants mostly stated that they wanted to be vaccinated due to the fear of transmitting the disease to the loved ones (41.5\%) whereas concerns about adverse events were the most common reason why the participants were unwilling to be vaccinated (27.9\%).

Conclusions: Vaccination refusal of one of every two HCPs, who are seen as a role model by society, will affect the success of controlling the Covid-19 pandemic. In conclusion, there is a need for an emergency action plan regarding the need for vaccination with scientific evidence.

Key Words: Covid-19; Healthcare professionals; Pandemic; Vaccination.

Öz.

Amaç: Sağlık çalışanlarının aşılanması bulaşııı hastalıklar yönünden önem arz eder. Bu çalışmanın amacı bir üniversite hastanesindeki sağlık çalışanlarının koronavirüs hastalığı 2019 (Covid-19) aşısına ilişkin görüşlerini ve aşılamaya etki eden faktörleri incelemektir.

Materyal ve Metod: Kesitsel tasarımlı bu çalıșma 09-12.12.2020 tarihleri arasında bir üniversite hastanesinde, gönüllü 183 sağlık çalışanı ile tamamlanmıştır. Çalışmada araştırmacılar tarafından geliştirilen 10 soruluk form kullanıImışır. Çalışma Harran Üniversitesi Etik Kurulu tarafından onaylanmışıı (09.11.2020; oturum: 19; karar no: HRU / 20.19.24). Ayrıca Türkiye Cumhuriyeti Sağlık Bakanlığı'ndan Covid-19 çalışma onayı alınmıştır.

Bulgular: Covid-19 aşısı yaptırmak isteyenlerin sıklı̆ı \%53,6 idi. Katııımcıların \%74,9'u Covid-19 aşısının, Covid-19 insidansını azaltmaya etkisi olacağını düşünüyordu. Covid-19 aşısı yaptırma durumu ile aşının Covid-19 insidansına etkisi arasında anlamlı bir fark olduğu saptandı $(p<0,001)$. Covid-19 aşısı yaptırmayı, erkek cinsiyete sahip olma 2,721, pandemi döneminde aşı yaptırma 0,356 ve Covid-19 aşısının insidansı azaltmaya etkisi olduğunu düşünme 19,272 kat etkilemektedir. Katılımcılar en çok sevdiklerine hastalık bulaştırma kaygısı $(\% 41,5)$ nedeni ile aşı olmak isterken, en çok yan etki kaygısı nedeniyle $(\% 27,9)$ aşı olmak istemediklerini bildirmişlerdir.

Sonuç: Toplumun rol model gördüğü sağlık çalışanlarının her ikisinden birinin aşı olmayı kabul etmemesi, Covid19 'un pandemisinin kontrol altına alınma başarısını etkileyecektir. Sonuç olarak, bilimsel kanıtlarla aşılanma gerekliliğine ilişkin acil eylem planına ihtiyaç vardır.

Anahtar kelimeler: Aşılama; Covid-19; Pandemi; Sağlık Profesyonelleri
Sorumlu Yazar / Corresponding Author

Şerif KURTULUŞ; M.D.

Harran University Faculty of Medicine, Department of Chest Diseases

Sanliurfa, Turkey.

E-mail: drkurtulus1@gmail.com

Geliş tarihi / Received:

01.04.2021

Kabul tarihi / Accepted:

13.04.2021

DOI: 10.35440/hutfd.908043

This study was presented as an oral presentation at the Joint Vaccine Symposium 2020 organized by Hacettepe University Vaccine Institute, December 11-13, 2020 


\section{Introduction}

The severe acute respiratory syndrome coronavirus 2 (SARS-CoV-2) originated from Wuhan, China in October 2019, and spread all over the world (1). The virus that causes acute respiratory diseases due to one or more unknown reasons is known to be associated with Severe Acute Respiratory Syndrome (SARS) and Middle Eastern Respiratory Syndrome (MERS) (2). Effective prophylactic agents are required to be developed rapidly to prevent this dramatic situation causing the deaths of millions (3). Many strategies, including DNA- and RNA-based vaccines, viral vector vaccines, inactivated vaccines, live attenuated viral vaccines, and recombinant protein vaccines, are used to develop vaccines for SARS-CoV-2. Vaccination is used to prevent infection as well as decreasing the transmission of the disease and disease severity (4). Health Care Professionals (HCPs), who are at higher risk of being infected compared to other populations, are recommended to be vaccinated to prevent contamination from patients and to protect their health $(5,6)$. Advices of HCPs regarding vaccination is one of the strongest factors influencing the decision-making process of society (6). Besides these facts, HCPs are known to experience different levels of hesitation against vaccination. Studies show that $4.3 \%$ to $76 \%$ of HCPs experience hesitation $(7,8)$. This study aimed to investigate the views of HCPs working in a university hospital about the coronavirus disease 2019 (Covid-19) vaccine and to evaluate the factors affecting vaccination.

For this purpose, answers to the following questions were sought in the study $(4,6)$ :

Research Questions

1) What is the rate of HCPs who are willing and unwilling to get the Covid-19 vaccine?

2) Does the fact that HCPs have had Covid-19 infection affect their thoughts on the Covid-19 vaccine?

3) Do HCPs think the Covid-19 vaccine will affect the incidence?

4) What are the reasons for willingness and unwillingness to get the Covid-19 vaccine?

5) What are the factors affecting the thoughts about getting the Covid-19 vaccine?

\section{Materials and Methods}

This study was designed as cross-sectional research.

\section{Study Population and Sample Size}

The universe of the study consisted of 504 HCPs (academicians, assistant doctors, nurses) working at the Harran University Hospital. The research was completed with a total of 183 HCPs (including 65 nurses, 64 academicians, and 54 assistant doctors), who were working in their unit during the research period and were volunteering to participate. The confidence interval of the study was calculated as $90 \%$ with 183 participants (calculation for confidence interval was used the Raosoft sample size calculator). This study was approved by the Harran University
Ethics Committee (09.11.2020; session: 19; decision no: HRU/20.19.24). In addition, the Ministry of Health's Covid-19 Study approval was received.

\section{Data Collection}

Researchers visited the units where the HCPs were working on 7-11 December 2020 and hand-delivered the data collection form to them. Participants were asked to fill the form through the self-report method. Participation in the study was on a voluntary basis. Completing one form took about 10 to 15 minutes.

The questionnaire developed by the researchers was used in the study. The form included questions about the followings: gender, age, occupation, units they were working at, whether they were working in a unit dedicated to Covid-19, working time in a unit dedicated to Covid-19, whether or not to have Covid-19 infection, presence of chronic disease, whether to get flu (influenza) or pneumococcal vaccine before and during the pandemic period, whether to get Covid-19 vaccine if it had been developed before and the reasons if the answer was yes (fear of illness or death, fear of transmitting the virus to their family and loved ones, being in the risk group, presence of a pandemic threat, other) or no (concerns about the adverse events, not believing in its effectiveness, feeling like a guinea pig, the fact that the vaccine had been newly developed, having to pay a fee, other), and whether they believed that the vaccine developed would reduce the incidence of Covid-19.

\section{Statistical Analysis}

Statistical analyses were performed using IBM SPSS Statistics for Windows version 23 software. Continuous variables were defined as mean \pm standard deviation and categorical variables were defined as number and percentage. Chi-square test was used to compare categorical variables. Binary logistic regression analysis was used to determine the independent predictors of the thoughts about getting Covid-19 vaccine. A $p$ value of $<0.05$ was considered as statistically significant.

\section{Results}

The mean age of the participants was $32.72 \pm 8,83$ years, ranging from 20 to 60 years. Of the participants, $62.8 \%$ were males, $29.5 \%$ were academicians, $35.5 \%$ were nurses and $35 \%$ were physician assistants. The rate of participants who reported working in clinical services was 63.3\%. $21.3 \%$ of the participants reported that they had Covid-19 infection. Participants' working time in a unit dedicated to Covid-19 ranged from zero to nine months, with a mean time of $1.96 \pm 2.53$ months (Table 1 ).

The rate of those reporting that they had a chronic disease was $13.7 \%$. While $17.5 \%$ of the participants reported that they got a vaccine before the pandemic, $39.9 \%$ reported that they got a vaccine during the pandemic period. The rate of HCPs who were willing to get the Covid19 vaccine was $53.6 \%$ (Table 2 ). Of the participants, $74.9 \%$ thought that the Covid-19 vaccine would have an effect 
on reducing the incidence (Table 2 ).

Table 1. Characteristic of participants

\begin{tabular}{|l|l|l|}
\hline & $\mathbf{n}$ & $\%$ \\
\hline $\begin{array}{l}\text { Age } \\
\text { Mean } \pm \text { SD, (Min-Max) }=32,72 \pm 8,83(20-60)\end{array}$ & & \\
\hline Gender & & \\
\hline Female & 68 & 37.2 \\
\hline Male & 115 & 62.8 \\
\hline Work & & \\
\hline Nurse & 65 & 35.5 \\
\hline Academic personel & 64 & 35.0 \\
\hline Asistant Doctor & 54 & 29.5 \\
\hline Department & & \\
\hline Services of Clinic & 76 & 63.3 \\
\hline Outpatient Clinic & 4 & 3.3 \\
\hline Intensive Care Unit & 40 & 33.3 \\
\hline Covid-19 Infection & & \\
\hline Yes & 39 & 21.3 \\
\hline No & 144 & 78.7 \\
\hline & & \\
\hline
\end{tabular}

Table 2. Distributions Regarding Vaccine Applications

\begin{tabular}{|c|c|c|}
\hline Do you have a Chronic Illness? & $\mathbf{n}$ & $\%$ \\
\hline Yes & 25 & 13.7 \\
\hline No & 158 & 86.3 \\
\hline \multicolumn{3}{|c|}{ Were You Vaccinated Before the Pandemic? } \\
\hline Yes & 25 & 13.7 \\
\hline No & 158 & 86.3 \\
\hline \multicolumn{3}{|c|}{ Have You Vaccinated During the Pandemic Period? } \\
\hline Yes & 73 & 39.9 \\
\hline No & 110 & 60.1 \\
\hline \multicolumn{3}{|c|}{ If you had the opportunity, would you get Covid-19 vaccine? } \\
\hline Yes & 98 & 53.6 \\
\hline No & 85 & 46.4 \\
\hline \multicolumn{3}{|c|}{$\begin{array}{l}\text { Do you think Covid Vaccine will have an effect on reducing the in- } \\
\text { cidence? }\end{array}$} \\
\hline Yes & 137 & 74.9 \\
\hline No & 42 & 23.0 \\
\hline Partially & 4 & 2.1 \\
\hline
\end{tabular}

When the thoughts of the participants about the Covid19 vaccination were examined according to their infection status, $53.8 \%$ of those who were willing to get the Covid-19 vaccine had the Covid-19 infection whereas $53.5 \%$ of them stated that they did not have Covid-19 infection. There was no difference between the thoughts on getting the Covid-19 vaccine and having Covid-19 infection (Table 3). Of those who were willing to be vaccinated, $65.7 \%$ reported that they thought the vaccine would reduce the incidence of Covid-19 infection, $16.7 \%$ stated that they thought the vaccine would not reduce the incidence of Covid-19 infection, and 25\% reported that they thought the vaccine would partially affect the incidence of Covid-19 infection. There was a significant difference between the thoughts about getting the Covid19 vaccine and the effect of the vaccine on the incidence of Covid-19 (Table 3).

The regression analysis showed that thoughts about getting the Covid-19 vaccine was found to be affected 2.721fold by the male gender (odds ratio [OR]: 1.2 - 5.9), 0.356- fold by getting vaccinated during the pandemic period (OR: $0.1-0.7$ ), and 19.272 -fold by the thought that the Covid-19 vaccine would reduce the incidence (OR :1.1 312.9) (Table 4).

Table 3. The Impact of Vaccination on Covid Infection and the Reduction of Covid-19 Incidence

\begin{tabular}{|c|c|c|c|}
\hline \multirow{2}{*}{ Covid-19 Infection Status } & \multicolumn{2}{|c|}{$\begin{array}{l}\text { Covid-19 Vaccination Sta- } \\
\text { tus }\end{array}$} & $\mathbf{p}$ \\
\hline & $\begin{array}{l}\text { Yes } \\
\mathrm{n}(\%)\end{array}$ & $\begin{array}{l}\text { No } \\
n(\%)\end{array}$ & \multirow[t]{3}{*}{0.556} \\
\hline Yes & $21(53.8)$ & $18(46.2)$ & \\
\hline No & $77(53.5)$ & $67(46.5)$ & \\
\hline \multicolumn{3}{|c|}{$\begin{array}{l}\text { The Impact of Vaccination on Reduction of } \\
\text { Covid Incidence }\end{array}$} & \multirow{4}{*}{0.001} \\
\hline Yes & $90(65.7)$ & $47(34.3)$ & \\
\hline No & $7(16.7)$ & $35(83.3)$ & \\
\hline Partially & $1(25.0)$ & $3(46.4)$ & \\
\hline
\end{tabular}

Table 4. Covid-19 vaccination Preferences

\begin{tabular}{|l|l|l|l|l|}
\hline Variables & OR & $\% 95-\mathrm{Cl}$ & SE & $\mathrm{p}$ \\
\hline Age & 1.053 & $\begin{array}{l}0.990- \\
1.119\end{array}$ & 0.031 & 0.102 \\
\hline Gender & 2.721 & $\begin{array}{l}1.247- \\
5.940\end{array}$ & 0.398 & 0.012 \\
\hline Working Covid space & 0.652 & $\begin{array}{l}0.309- \\
1.374\end{array}$ & 0.380 & 0.261 \\
\hline $\begin{array}{l}\text { Status of Covid-19 in- } \\
\text { fection }\end{array}$ & 1.606 & $0.692-$ & 0.430 & 0.271 \\
\hline $\begin{array}{l}\text { Status of Choronic Di- } \\
\text { sease }\end{array}$ & 0.484 & $\begin{array}{l}0.162- \\
1.448\end{array}$ & 0.559 & 0.194 \\
\hline $\begin{array}{l}\text { Vaccinated Before } \\
\text { the Pandemic }\end{array}$ & 0.836 & $0.288-$ & 0.544 & 0.742 \\
\hline $\begin{array}{l}\text { Vaccinatied During } \\
\text { the Pandemic }\end{array}$ & 0.356 & $0.165-$ & 0.390 & 0.008 \\
\hline $\begin{array}{l}\text { The Impact of Vacci- } \\
\text { nation on Reduction } \\
\text { of Covid Incidence }\end{array}$ & 19.272 & $\begin{array}{l}1.187- \\
0.765\end{array}$ & 1.422 & 0.037 \\
\hline
\end{tabular}

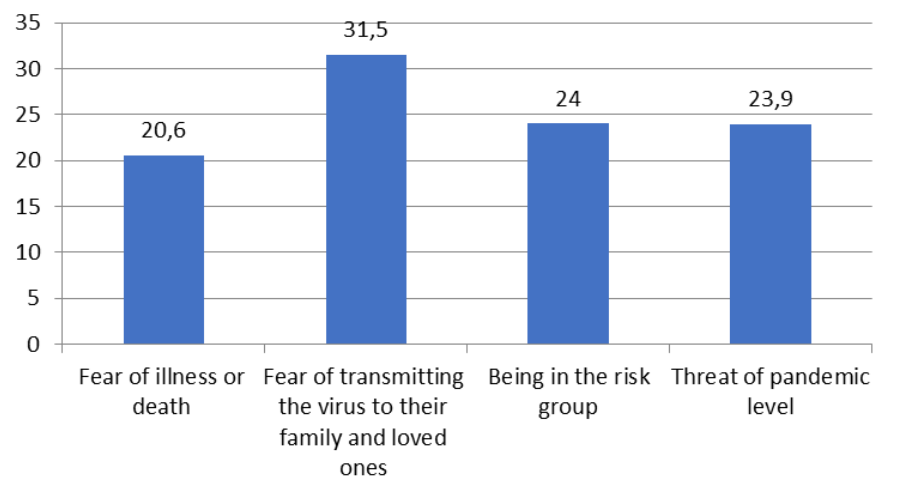

Figure 1. The most frequently reported reason for willingness to be vaccinated

Participants who answered yes to the question 'would you get the Covid-19 vaccine?' were observed to be willing to be vaccinated mostly due to the fear of transmitting the virus to their family and loved ones (41.5\%); $29 \%$ stated that they were willing to be vaccinated since they 
were in the risk group and $24.5 \%$ due to fear of illness or death (Figure 1).

The most frequently reported reason for unwillingness to be vaccinated was observed to be possible adverse events $(27.9 \%)$, followed by the fact that the vaccine had been newly developed (22.4\%), feeling like a guinea pig $(13.7 \%)$, not believing in the effectiveness of the vaccine $(10.9 \%)$ and having to pay a fee $(0.5 \%)$ (Figure 2 ).

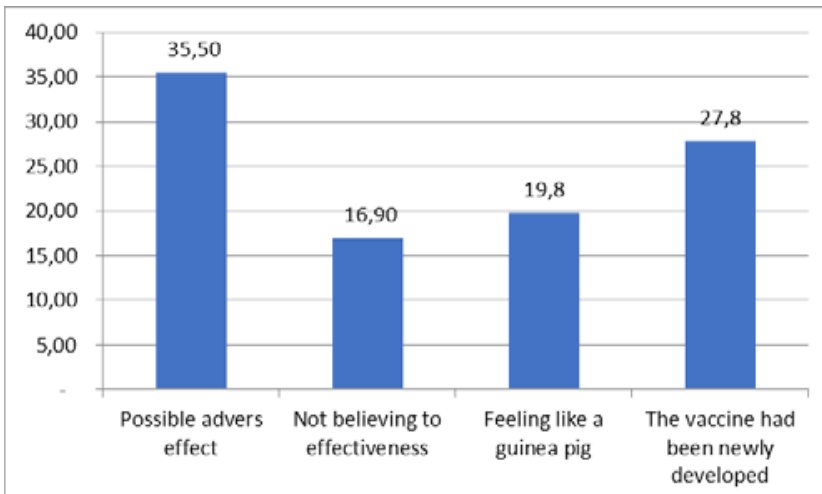

Figure 2. The most frequently reported reason for unwillingness to be vaccinated

\section{Discussion}

This cross-sectional study has investigated the attitudes of 183 HCPs working in a university hospital towards the Covid-19 vaccine. One of every two HCPs (53.6\%) reported that they wanted to be vaccinated. In addition, there was a significant difference between the thoughts about getting the Covid-19 vaccine and the thought that the vaccine would reduce the incidence of the disease. The majority of the participants stated that they wanted to be vaccinated due to fear of transmitting the disease to the loved ones whereas concerns about adverse events were the most common reason for unwillingness to be vaccinated. The results of the present study have shown that having a male gender, vaccination during the pandemic period and the thought that the Covid-19 vaccine will reduce the incidence of the disease are factors that affect the willingness to get the Covid-19 vaccine.

The incidence of influenza infection in HCPs is higher than in other individuals. The presence of influenza among HCPs causes labor loss, disruption of health services, and additional costs. Furthermore, infected HCPs increase the disease burden by transmitting the virus to patients and colleagues. Therefore, prevention of influenza among HCPs is of great importance (9). Findings obtained from the present study showed that almost two out of ten HCPs (17.5\%) had vaccinations such as pneumococcal and seasonal influenza vaccines in the pre-pandemic period. There are studies reporting different vaccination rates in the literature. In a study involving 889 physicians from the infection control committee and nurses from 56 countries, the vaccination rate was reported to be the highest in Finland, Israel, Portugal, and Norway (100\%) whereas this rate was $39 \%$ in Turkey (8). In a study by Solay et al. (7) conducted in 2020,10.4\% of HCPs were observed to have the seasonal flu vaccine. Kul and Korkmaz asked 371 participants whether they had influenza vaccine and found that $134(36.1 \%)$ of them get vaccinated at least once in their lives (10). Different vaccination rates in the literature and the present study may be due to any legal or cultural reasons. Religiosity and use of alternative medicine, family lifestyle, perceived disease risks, vaccine efficacy and side effects, concerns about vaccine safety, perceived advantages, previous negative experience with vaccination, and social environment are among the cultural reasons for vaccination hesitation / rejection (11). Contrary to the low vaccination rates in Turkey, it is known that $78.4 \%$ of HCPs in the United States received vaccination in the $2017-2018$ season and $80.6 \%$ in the 2019-2020 season (12). In the present study, the rate of seasonal influenza or pneumococcal vaccination was observed to increase during the pandemic period (39.9\%). In other words, the number of HCPs receiving pneumococcal and seasonal influenza vaccination increased during the pandemic period (four out of ten people), showing that particularly HCPs try to protect their health more during the pandemic period. In a study conducted by Fournet et al. (13) in 2018, the rate of seasonal flu vaccination among HCPs was observed to increase compared to the previous year. Findings in the literature and obtained from the present study support the view that vaccination is considered as the strongest shield that both reduces costs and protects people from disease in all societies.

The vaccination coverage also varies among HCPs. In a systematic review of 37 studies investigating factors related to vaccination, doctors were reported to have a more positive attitude towards the vaccination while nurses had a negative attitude (14). According to data reported by the Centers for Disease Control and Prevention $(C D C)$, the flu vaccination coverage is highest among physicians $(98.0 \%)$, followed by nurses $(92.0 \%)$ and physician assistants (88.8\%) (12). Keske et al. (8) stated that being a scientific authority was an important factor in vaccination and that the rate of vaccination was higher among physicians compared to nurses and other HCPs. In a study conducted for the acceptance and implementation of the Covid-19 vaccine in Malta, influenza vaccination coverage was found to be higher among physicians compared to nurses and the rates were found to be similar in 2020 (13). In a study by Fu et al. (6) involving Chinese HCPs, three-quarters of the participants reported that they would get the Covid-19 vaccine. In the present study, the overall rate of HCPs who wanted to get the Covid-19 vaccine was found to be $53.92 \%$. HCPs who were willing to get the Covid-19 vaccine were found to be academicians (61.1\%), physician assistants (56.3\%), and nurses (44.6\%), respectively Grech et al. (13) (2020) reported that the number of physicians who would get the Covid-19 vaccine 
was higher compared to nurses. Shehar et al. (2021) reported in their study that 36 were willing to get the vaccine as soon as possible, and 56 were not sure to willing to get the vaccine (15).

In the present study, one of every two HCPs (53.8\%) who had the Covid-19 infection wanted to get the Covid-19 vaccine whereas the rate of those who were unwilling to be vaccinated despite having had Covid-19 infection was $53.5 \%$. In other words, regardless of whether or not they have had Covid-19 infection, HCPs have similar attitudes towards vaccination. Vaccination and vaccine hesitancy is a known fact $(16,17)$. However, personal precautions alone are not sufficient to control the disease caused by a virus that leads to the deaths of millions. For this reason, vaccine hesitancy should be avoided by combining both legal and administrative mechanisms. Health-care professionals have important responsibilities in this regard, both to protect their own health and to raise awareness of society.

According to the present findings, $65.7 \%$ of HCPs, who want to get the Covid-19 vaccine, believe that vaccination will reduce the incidence of disease. Although they want to get the Covid-19 vaccine, $25.0 \%$ of HCPs believe that the vaccine will have a partial effect on the incidence and $16.7 \%$ of HCPs believe that the vaccine will not affect the incidence. This significant difference shows that HCPs rely on vaccination, particularly in outbreaks that affect a large proportion of the population such as pandemics. In the Keske et al.'s (8) study, $87 \%$ of the participants thought that the effectiveness of the influenza vaccine was more than $80 \%(8)$.

There are several factors that affect the males' risk-taking tends $(18,19)$. Therefore, they may show more assertive behaviours in the occurrence of a new situation. In the present study, the male gender was observed to increase the vaccination status two-fold. In a study from Malta, males were found to more tend to be vaccinated, similar to the present study (13). Having vaccinated in another pandemic period, except for the Covid-19 pandemic, and believing that the Covid-19 vaccine would reduce the incidence were found to be the factors affecting the thoughts about getting the Covid-19 vaccine.

In the present study, the reasons why HCPs isn't wanted to be vaccination; fear of transmitting the virus to the loved ones, being in the risk group, and fear of illness or death. In a study by Fu et al. (6) regarding the acceptance of Covid-19 vaccine by HCPs, factors influencing vaccine acceptance were reported to be as follows: seasonal flu, resistance, vaccination of those who had social contacts, high probability of infection, fee, vaccine efficacy, and safety. Similar to the present study, Keske et al. (8) and Bish et al. (14) reported that self-protection and protection of family members, being in the risk group, and believing in the efficacy of the vaccine were positive motivators for vaccination. Keske et al. (8) reported the leading motivators of vaccination were free availability of the vaccine and willingness to be a role model (8). In our study, the reasons why the HCPs who were unwilling to receive the vaccine were found to be as follows: concerns about the adverse events, the fact that the vaccine had been newly developed, feeling like a guinea pig, not believing in its effectiveness, and having to pay a fee. Suspicions about vaccine efficacy, possibility of adverse events, and being anti-vaxxer were the most common reasons for vaccine rejection $(8,13,14)$. Keske et al. (8) further reported that being in Turkey caused negative intentions towards vaccination. HCPs are among the leading groups at high risk of becoming infected in the pandemic starting in 2019 (6). Vaccination practices have been initiated rapidly in different parts of the world to protect HCPs and society from Covid-19. Vaccines developed at an unprecedented pace cause hesitancy among HCPs; which is important for both their own health and the health of the patients they are in contact with (20).

Limitations

While this study reveals the hesitation / intention for COVID-19 vaccine, it is insufficient to reveal additional factors that may be specific to a particular virus and population. Another limitation is that it is a cross-sectional study that cannot infer the causal relationship. As well as, the sample size is limited.

\section{Conclusion}

The existing pandemic can be only taken under control by vaccination. Hesitations of HCPs regarding vaccination and related barriers need to be overcome. Providing scientific information sharing among HCPs may increase vaccination coverage. Vaccination will not only help HCPs protect themselves but also ensure that they will serve as a role model for society to increase vaccination coverage.

Ethical Approval: This study was approved by the Harran University Ethics Committee (09.11.2020; session: 19; decision no: HRU / 20.19.24). In addition, the Ministry of Health's Covid-19 Study approval was received.

\section{Author Contributions:}

Concept: Ş.K., R.C.

Literature Review: S.K.,R.C.

Design : Ş.K.,R.C.

Data acquisition: Ş.K.,R.C.

Analysis and interpretation Ş.K.,R.C.

Writing manuscript: Ş.K.,R.C.

Critical revision of manuscript: Ş.K.,R.C.

Conflict of Interest: Authors declared no conflict of interest.

Financial Disclosure: Authors declared no financial support.

\section{References}

1. Annakkaya A, Yıldız Gülhan P, Güleç Balbay E, Balbay Ö, Arbak P. Göğüs Hastalıkları Kliniği, Pandemi Tecrübeleri. Konuralp Med J. 2020;12(S1): 361-3.

2. Zhu N, Zhang D, Wang W, Li X, Yang B, Song J, et al. A novel coronavirus from patients with pneumonia in China, 2019. N Engl J Med. 2020;382:727-33

3. Salvatori G, Luberto L, Maffei M, Aurisicchio L. Roscilli G, 
Palombı F, et al. SARS-CoV-2 Spike Protein: an optimal immunological target for vaccines. J Transl Med 2020;18:222.

4. Liu X, Liu C, Liu G, Luo W, Xia N. COVID-19: Progress in diagnostics, therapy and vaccination. Theranostics. 2020;10(17):7821-7835.

5. Dini G, Toletone A, Sticchi L, Orsi A, Bragazzi NL, Durando $P$. Influenza vaccination in healthcare workers:A comprehensive critical appraisal of the literature. Hum vaccin immunother. 2018;14(3):772-89.

6. Koruk I, Tekin-Koruk S, Tuncer K, Demir C, Kara B, Seyhanoglu AS. The immunization level of healthcare workers against occupational infectious diseases in sanliurfa. KLIMIK journal. 2014;27(2):48-56.

7. Haykır Solay A, Uzar H. Acar A, Eser F, Duman Z, Sencan I, et al. Health Workers' Attitudes Toward Influenza Vaccine, Vaccination Rates, and Incidence of Nosocomial Influenza in a Tertiary Care Center. Journal of ANKEM 2020;34(1):612

8. Keske Ş, Mutters NT, Tsioutis C, Ergönül Ö. EUCIC influenza vaccination survey team. Influenza vaccination among infection control teams: A EUCIC survey prior to COVID-19 pandemic. Vaccine 2020;14;38(52):8357-61.

9. Azap A. How to Prevent Influenza Among Health Care Workers. Turkey Clinics J Inf Dis-Special Topics. 2015;8(1):15-9

10. Kul G, Korkmaz N. The Approach of Health Care Workers to Influenza Vaccination J Contemp Med 2020;10(3):421-4

11. Yüksel GH, Topuzoğlu A. Aşı Redlerinin Artması ve Aşı Karşıtlığını Etkileyen Faktörler. ESTÜDAM Halk Sağlığı Dergisi. 2019;4:244-58

12. Razzaghi $H$, Kahn KE, Black CL, Lindley $M C$, Jatlaoui $T C$, Fiebelkorn AP, et al. Influenza and Tdap Vaccination Coverage Among Pregnant women - United States, MMWR. 2020;69:1391-7

13. Fournet $N$, Mollema L, Ruijs $W L$, Harmsen IA, Keck F, Durand $J Y$, et al. Under-vaccinated groups in Europe and their beliefs, attitudes and reasons for non-vaccination; two systematic reviews. BMC Public Health. 2018;18:196.

14. Bish A, Yardley L, Nicoll A, Michie S. Factors associated with uptake of vaccination against pandemic influenza: A systematic review. Vaccine. 2011;29(38);6472-84.

15. Shekhar R, Sheikh AB, Upadhyay $S$, Singh $M$, Kottewar $S$, Mir $\mathrm{H}$, et al. Covid-19 Vaccine Acceptance among Health Care Workers in the United States. Vaccines (Basel). 2021;9(2):119

16. Lau LHW, Lee SS, Wong NS. The continuum of influenza vaccine hesitancy among nursing professionals in Hong Kong. Vaccine. 2020;38(43):6785-93

17. Di Martino G, Di Giovanni P, Di Girolamo A, Scampoli $P$, Cedrone $F$, D'Addezzio $M$, et al. Knowledge and attitude towards vaccination among healthcare workers: a multicenter cross-sectional study in a Southern Italian Region. Vaccines (Basel). 2020;8(2):248.

18. C Turner, R McClure. Age and gender differences in risk-taking behaviour as an explanation for high incidence of motor vehicle crashes as a driver in young males, Inj. Control. Saf. Promot. 2003;10(3):123-30,

19. Günal Ö, Türe E, Bayburtlu M, Arslan U, Demirağ MD, Taşkın MH, et al. Evaluation of Patients Diagnosed with Covid19 in Terms of Risk Factors. Mikrobiyol Bul 2020;54(4):629637.

20. Caddy S. Developing a vaccine for Covid19 BMJ 2020;369:m1790 